\title{
PERBANDINGAN EFEKTIVITAS MEDIUM SHOOT DENGAN LONCATAN DAN TANPA LONCATAN TERHADAP AKURASI HASIL SHOOTING
}

\author{
Oleh \\ Fakhri Fajrin Kurniawan ${ }^{1}$ \\ ${ }^{1}$ Universitas Muhammadiyah Cirebon \\ Email: fakhry.fajrin@umc.ac.id
}

\begin{abstract}
Abstrak
Penelitian ini bertujuan untuk mengetahui atau memperoleh informasi tentang efektivitas penggunaan teknik medium shoot dengan loncatan dan tanpa loncatan terhadap ketepatan hasil shooting. Metode penelitian yang digunakan adalah metode deskriptif melalui observasi atau survei langsung terhadap suatu pertandingan. Populasi penelitian adalah seluruh pertandingan pada Kejuaraan Bola Basket Pekan Olahraga Wilayah (POPWIL) Se-Wilayah III Cirebon Tahun 2019. Sampel ditentukan dengan menggunakan teknik total sampling. Dimana dari seluruh pertandingan pertama sampai terakhir dijadikan sebagai sampel. Instrument penelitian yang digunakan adalah dengan cara ratting oleh 4 orang juri atau testor. Hasil pengolahan data dengan penghitungan secara statistika yang menggunakan penghitungan uji dua pihak (uji t), diperoleh hasil bahwa thitung 0,47 dan $t_{\text {tabel }}$ 2,07 dengan kesimpulan hipotesis diterima. Berdasarkan hal tersebut maka tidak terdapat perbedaan yang berarti antara medium shoot dengan loncatan dan tanpa loncatan terhadap ketepatan hasil shooting. Namun teknik medium shoot dengan loncatan lebih efektif digunakan untuk memperoleh poin pada Kejuaraan Bola Basket Pekan Olahraga Wilayah (POPWIL) Se-Wilayah III Cirebon.
\end{abstract}

Kata kunci: Efektivitas, Medium Shoot, Bola Basket

\section{A. PENDAHULUAN}

Dalam permainan bola basket setiap regunya terdiri dari lima orang, yang mana setiap posisi pemain secara umum telah ditentukan posisinya sebagai berikut : pemain satu sebagai point guard (best ball handler), pemain dua sebagai shooting guard (best outside shooting), pemain tiga sebagai small forward (versatile inside player), pemain empat sebagai power forward (strong rebounding forward), pemain lima sebagai post/centre (inside score rebounder).

Secara umum unsur atau teknik dasar dalam permainan bola basket terdiri dari : dribble (menggiring bola), passing (mengoper bola), dan shooting (menembak). Shooting (menembak) adalah "Keahlian yang sangat penting di dalam olahraga basket. Shooting itu sendiri memiliki beberapa cara walaupun pada dasarnya bertujuan sama, yaitu memasukan bola ke ring." 
Salah satu shooting dalam permainan bola basket adalah medium shoot yaitu tembakan dari sekitar high post (area two point). Dan dalam sebuah pertandingan tujuan melakukan shooting adalah memasukan bola ke ring lawan dan mendapatkan point. Dalam melakukan ketrampilan shooting terdapat berbagai cara melakukannya antara lain shooting menggunakan loncatan atau tanpa loncatan. Begitupun dengan ketrampilan medium shoot terdapat berbagai cara melakukannya antara lain medium shoot menggunakan loncatan atau tanpa loncatan. Medium shoot memakai loncatan maksudnya adalah melakukan shooting dengan diawali dengan loncatan terlebih dahulu. Shooting ini biasanya dilakukan oleh pemain untuk mendapatkan hasil yang lebih baik lagi. Sedangkan medium shoot tanpa loncatan adalah melakukan shooting dengan berdiri di tempat dengan tidak meloncat ataupun melompat. Shooting ini biasanya dilakukan pada waktu pemain sudah mendribble bola, lalu bola sulit untuk dioperkan jadi pemain melakukan shooting dengan diam di tempat. Namun sampai sekarang ini keefektifan antara medium shoot dengan loncatan dan tanpa loncatan terhadap hasil poin masih belum jelas adanya.

Berdasarkan penjelasan di atas, kiranya perlu diadakan penelitian langsung dari suatu pertandingan. Terutama shooting dengan teknik medium shoot. Hal ini dikarenakan medium shoot berada di area high post atau area two point, yang di daerah tersebut sering terjadi gerakan shooting dengan menggunakan loncatan dan tanpa loncatan. Maka penulis tertarik mengadakan penelitian langsung dari pertandingan. Hal ini sebagai bukti ilmiah yang mendukung teori bahwa adanya perbandingan keefektifan medium shoot dengan loncatan dan tanpa loncatan dalam ketepatan hasil shooting.

\section{Teknik Dasar Shooting (Menembak)}

Ketrampilan terpenting dalam permainan bola basket adalah kemampuan untuk melakukan shooting atau menembak bola ke dalam keranjang. Shooting (menembak) merupakan keahlian yang sangat penting di dalam olahraga basket. Shooting atau menembak merupakan suatu ketrampilan dalam menyerang yang paling ampuh dan terpenting diantara berbagai ketrampilan teknik menyerang.

Ada istilah berkaitan dengan teknik shooting dalam bola basket yang perlu dikenalkan kepada pemain sejak dini, yaitu BEEF : B (Balance) yaitu gerakan selalu dimulai dari lantai, saat mengakap bola tekuklah lutut dan mata kaki serta atur agar tubuh dalam posisi seimbang ; E (Eyes) yaitu agar shooting menjadi akurat pemain 
harus dengan segera mengambil fokus pada target (pemain dengan cepat mampu mengkoordinasikan letak ring) ; E (Elbow) yaitu pertahankan posisi siku agar pergerakan lengan akan tetap vertikal ; F (Follow through) yaitu kunci siku lalu lepaskan gerakan lengan jari-jari dan pergelangan tangan mengikuti ke arah ring.

\section{Teknik Medium Shoot}

Tembakan medium shoot adalah tembakan dari sekitar high post (Posisi pemain poros di garis tembakan atau area two point). Tembakan ini merupakan tembakan yang paling efisien dan banyak digunakan oleh pemain di lapangan, karena merupakan satu gerakan yang simpel untuk menghasilkan angka, namun tentunya setiap teknik gerakan mempunyai resiko tersendiri, begitupun dengan teknik medium shoot ini. Selain membutuhkan otomatisasi tembakan yang baik dari pemain, teknik ini juga beresiko tinggi di blok oleh lawan jika timing tembakan tidak benar dan penjagaan dari lawan yang ekstra ketat.

a. Medium Shoot dengan Loncatan

Medium shoot dengan loncatan yaitu shooting dengan diawali dengan loncatan terlebih dahulu. Tembakan ini paling umum dilakukan oleh pemain dalam permainan bola basket karena tembakan ini adalah tembakan dasar/umum yang dilakukan dengan melompat untuk lebih mudah dalam mencapai ring.

\section{b. Medium Shoot tanpa Loncatan}

Medium shoot tanpa loncatan yaitu shooting tanpa diawali dengan loncatan terlebih dahulu. Medium shoot tanpa loncatan merupakan tembakan sangat efektif yang sulit dibendung oleh lawan, maka perlu dimahirkan menjadi penguasaan para pemain, umumnya para penembak yang sudah baik baru melepaskan tembakan saat mencapai titik keseimbangan. Seorang pemain yang dapat melakukan tembakan medium shoot tanpa loncatan dengan baik merupakan ancaman yang berbahaya bagi lawan-lawannya dalam mencetak angka. Apabila ia menguasai bola, ia dapat mencetak angka setiap saat. Sebab pemain tersebut dapat melakukan tembakan medium shoot dari situasi apapun, misalnya selagi ia melakukan dribble, dari menerima umpan baik dalam keadaan diam atau bergerak. Dari hal tersebut dapat disimpulkan medium shoot tanpa loncatan merupakan salah satu tembakan yang dilakukan didalam permainan bola basket untuk memasukkan bola ke ring lawan dan memperoleh angka. 
Teknik medium shoot ini dapat diuraikan dalam fase-fase sebagai berikut :

a. Fase persiapan

Kaki, bahu terentang lebar, jari-jari kaki lurus, lutut lentur, bahu rileks, tangan yang tidak menembak di samping bola, tangan menembak di belakang bola, ibu jari rileks, siku masuk, bola pada posisi tinggi di antara telinga dan bahu, lihat target.

b. Fase pelaksanaan

Lompat, lalu tembak (untuk medium shoot dengan loncatan), rentangkan kaki, punggung, dan bahu, rentangkan siku, lenturkan pinggang dan jari-jari ke depan, lepaskan jari telunjuk, laju penyeimbang pada bola sampai terlepas, irama yang sama, lihat target.

c. Fase follow-through

Rentangkan lengan, jari telunjuk menunjuk pada target, telapak tangan ke bawah saat menembak, seimbangkan dengan telapak tangan ke atas, lihat target, mendarat dengan seimbang (untuk medium shoot dengan loncatan).

\section{B. METODOLOGI PENELITIAN}

Metode penelitian yang penulis pilih adalah metode deskriptif. Metode ini digunakan atas pertimbangan karena sifat penelitian yang penulis lakukan yaitu bersifat menggambarkan data yang ada yaitu untuk mengetahui efektifitas medium shoot dengan loncatan dan tanpa loncatan terhadap ketepatan hasil shooting pada Kejuaraan Bola Basket Pekan Olahraga Wilayah (POPWIL) Se-Wilayah III Cirebon. Populasi yang gunakan dalam penelitian ini adalah seluruh pertandingan pada Kejuaraan Bola Basket Pekan Olahraga Wilayah (POPWIL) Se-Wilayah III Cirebon Tahun 2019. Teknik pengambilan sampel yang penulis lakukan yaitu dengan teknik total sampling. Dimana dari seluruh pertandingan pertama sampai terakhir dijadikan sebagai sampel.

\section{HASIL DAN PEMBAHASAN PENELITIAN}

1. Hasil Penelitian

Tabel 1

Hasil Medium Shoot dengan Loncatan dan Tanpa Loncatan

\begin{tabular}{cccccccc}
\hline \multirow{2}{*}{ No } & \multirow{2}{*}{ Nama Tim } & \multicolumn{2}{c}{ Dengan Loncatan } & \multirow{2}{*}{ Nilai } & \multicolumn{2}{c}{ Tanpa Loncatan } & \multirow{2}{*}{ Nilai } \\
\cline { 3 - 4 } & & Kesempatan & Berhasil & & Kesempatan & Berhasil & \\
\hline 1. & Kab. Kuningan (PI) & 44 & 20 & 45 & 23 & 10 & 44 \\
\hline 2. & Kab. Cirebon (PI) & 49 & 16 & 33 & 22 & 8 & 36 \\
\hline 3. & Kota Cirebon (PI) & 55 & 23 & 42 & 20 & 11 & 55 \\
\hline 4. & Kab. Sumedang (PI) & 41 & 16 & 39 & 20 & 7 & 35 \\
\hline
\end{tabular}




\begin{tabular}{clcccccc}
\hline 5. & Kab. Majalengka (PI) & 12 & 10 & 83 & 6 & 2 & 33 \\
\hline 6. & Kab. Indramayu (PI) & 23 & 7 & 30 & 6 & 2 & 33 \\
\hline 7. & Kab. Kuningan (PA) & 7 & 5 & 71 & 3 & 2 & 67 \\
\hline 8. & Kab. Cirebon (PA) & 27 & 10 & 37 & 11 & 7 & 64 \\
\hline 9. & Kota Cirebon (PA) & 33 & 13 & 39 & 23 & 9 & 39 \\
\hline 10. & Kab. Sumedang (PA) & 43 & 14 & 33 & 15 & 7 & 47 \\
\hline 11. & Kab. Majalengka (PA) & 19 & 10 & 53 & 14 & 5 & 36 \\
\hline 12. & Kab. Indramayu (PA) & 31 & 17 & 55 & 33 & 13 & 39 \\
\hline
\end{tabular}

\section{Uji Homogenitas}

$\left.\mathrm{F}=\frac{\mathrm{S} 1^{2}}{\mathrm{~S} 2^{2}}=\frac{256,0}{141,61}=1,81\right] \quad$ Homogen
$\mathrm{F} 0,95(12 ; 12)=2,69$

\section{Pengujian Hipotesis}

Uji Hipotesis : Uji Kesamaan Dua Rata-rata Uji Dua Pihak

Kesimpulan :

$\left.\begin{array}{ll}\mathrm{t}_{\text {hitung }} & =0,47 \\ \mathrm{t}_{\text {tabel }} & =2,02\end{array}\right] \quad \begin{aligned} & \text { Tidak terdapat perbedaan yang berarti } \\ & \end{aligned}$

Keduanya sama- sama efektif digunakan untuk mencetak angka.

Tabel 2

Medium Shoot dengan Loncatan

\begin{tabular}{|c|c|c|c|c|c|c|c|}
\hline Skor & $(\mathrm{X}-\mathrm{X})^{-}$ & $(X-X)^{2}$ & $\mathrm{Zi}$ & $0-\mathrm{Z}$ & $\mathrm{F}(\mathrm{Zi})$ & $\mathrm{S}(\mathrm{Zi})$ & $\begin{array}{c}{[\mathrm{F}(\mathrm{Zi})-} \\
\mathrm{S}(\mathrm{Zi})\end{array}$ \\
\hline 30 & $-16,7$ & 278,89 & $-1,04$ & 0,3508 & 0,1492 & 0,0833 & 0,0659 \\
\hline 33 & $-13,7$ & 187,69 & $-0,86$ & 0,3051 & 0,1949 & 0,1667 & 0,0282 \\
\hline 33 & $-13,7$ & 187,69 & $-0,86$ & 0,3051 & 0,1949 & 0,2500 & 0,0551 \\
\hline 37 & $-9,7$ & 94,09 & $-0,61$ & 0,2291 & 0,2709 & 0,3333 & 0,0624 \\
\hline 39 & $-7,7$ & 59,29 & $-0,48$ & 0,1844 & 0,3156 & 0,4167 & 0,1011 \\
\hline 39 & $-7,7$ & 59,29 & $-0,48$ & 0,1844 & 0,3156 & 0,5000 & 0,1844 \\
\hline 42 & $-4,7$ & 22,09 & $-0,29$ & 0,1141 & 0,3859 & 0,5833 & 0,1974 \\
\hline 45 & $-1,7$ & 2,89 & $-0,11$ & 0,0438 & 0,4562 & 0,6667 & 0,2105 \\
\hline 53 & 6,3 & 39,69 & 0,39 & 0,1517 & 0,6517 & 0,7500 & 0,0983 \\
\hline 55 & 8,3 & 68,89 & 0,52 & 0,1985 & 0,6985 & 0,8333 & 0,1348 \\
\hline \multirow[t]{2}{*}{71} & 24,3 & 590,49 & 1,52 & 0,4357 & 0,9357 & 0,9167 & 0,0190 \\
\hline & 36,3 & 1317,69 & 2,27 & 0,4884 & 0,9884 & 1,0000 & 0,0116 \\
\hline 560 & & 2808,68 & & & & & \\
\hline
\end{tabular}

Kriteria Penerimaan

Lo $=0,2105$

Lt $0,95(12)=0,242$

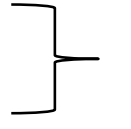

Normal 
Tabel 3

Medium Shoot tanpa Loncatan

\begin{tabular}{cccccccc}
\hline Skor & $(\mathrm{X}-\mathrm{X})^{-}$ & $(\mathrm{X}-\mathrm{X})^{2}$ & $\mathrm{Zi}$ & $0-\mathrm{Z}$ & $\mathrm{F}(\mathrm{Zi})$ & $\mathrm{S}(\mathrm{Zi})$ & {$[\mathrm{F}(\mathrm{Zi})-\mathrm{S}(\mathrm{Zi})$} \\
\hline 33 & -11 & 121 & $-0,92$ & 0,3212 & 0,1788 & 0,0833 & 0,0945 \\
\hline 33 & -11 & 121 & $-0,92$ & 0,3212 & 0,1788 & 0,1667 & 0,0121 \\
\hline 35 & -9 & 81 & $-0,76$ & 0,2764 & 0,2236 & 0,2500 & 0,0264 \\
\hline 36 & -8 & 64 & $-0,67$ & 0,2486 & 0,2514 & 0,3333 & 0,0819 \\
\hline 36 & -8 & 64 & $-0,67$ & 0,2486 & 0,2514 & 0,4167 & 0,1653 \\
\hline 39 & -5 & 25 & $-0,42$ & 0,1628 & 0,3372 & 0,5000 & 0,1628 \\
\hline 39 & -5 & 25 & $-0,42$ & 0,1628 & 0,3372 & 0,5833 & 0,2401 \\
\hline 44 & 0 & 0 & 0,00 & 0,0000 & 0,5000 & 0,6667 & 0,1667 \\
\hline 47 & 3 & 9 & 0,25 & 0,0987 & 0,5987 & 0,7500 & 0,1513 \\
\hline 55 & 11 & 121 & 0,92 & 0,3212 & 0,8212 & 0,8333 & 0,0121 \\
\hline 64 & 20 & 400 & 1,68 & 0,4535 & 0,9535 & 0,9167 & 0,0368 \\
\hline 67 & 23 & 529 & 1,93 & 0,4732 & 0,9732 & 1,000 & 0,0268 \\
\hline 528 & & 1560 & & & & & \\
\hline
\end{tabular}

Kriteria Penerimaan

$\mathrm{Lo}=0,2401$

Lt $0,95(12)=0,242$

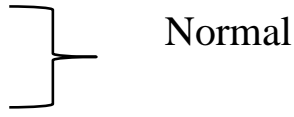

Tabel 4

Hasil Perhitungan dan Pengujian Hipotesis

\begin{tabular}{|c|c|c|c|}
\hline Kelompok Variabel & $\mathrm{t}$ hitung & $\mathrm{t}$ tabel $\left(1 \frac{1}{2} \alpha\right)(\mathrm{n}-1)$ & Kesimpulan \\
\hline $\begin{array}{c}\text { Medium Shoot } \\
\text { Dengan Loncatan }\end{array}$ & 0,47 & 2,07 & $\begin{array}{c}\text { Hipotesis } \\
\text { diterima }\end{array}$ \\
\hline $\begin{array}{l}\text { Medium Shoot } \\
\text { Tanpa Loncatan }\end{array}$ & & & \\
\hline
\end{tabular}

Berdasarkan tabel tesebut dapat disimpulkan bahwa, nilai $\mathrm{t}$ hitung lebih kecil dari $\mathrm{t}$ tabel pada $(a)=0,05, \mathrm{dk}=n_{1}+n_{2}-2$ dan berada di dalam daerah penerimaan hipotesis nol (Ho). Ini berarti hipotesis nol (Ho) diterima.

2. Pembahasan Penelitian

Berdasarkan pengujian hipotesis yang telah dibahas sebelumnya, dapat disimpulkan bahwa Perbandingan Efektivitas Medium Shoot Dengan Loncatan dan Tanpa Loncatan Terhadap Ketepatan Hasil Shooting Dalam Permainan Bola Basket 
keduanya sama efektifnya bila digunakan untuk mencetak angka, dan tidak terdapat perbedaan yang berarti dengan $t_{\text {hitung }}=0,47$ dan $t_{\text {tabel }}=2,02$.

- Adapun perbandingan kriteria penerimaannya, Medium Shoot dengan Loncatan Lo = 0,2105 dengan Lt 0,95 (12) = 0,242 dan Medium Shoot tanpa Loncatan Lo = 0,2401 dengan Lt 0,95 (12) = 0,242. Hal ini berarti itu medium dengan loncatan lebih efektif daripada medium shoot tanpa loncatan pada Kejuaraan Bola Basket Pekan Olahraga Wilayah (POPWIL) Se-Wilayah III Cirebon Tahun 2019. Tetapi dari keseluruhan masih terdapat beberapa kelemahan yang harus diperbaiki pada penelitian yang mendatang, hal ini dimungkinkan perlu adanya revisi pada bagian tertentu antara lain :

a) Penelitian dan analisis lebih mendalam terkait teknik shooting dalam sebuah pertandingan

b) Pemahaman pelatih terhadap materi shooting dalam pertandingan harus lebih variatif dan bisa baca permainan lawan, sehingga ini berjalan lebih efektif dan efesien

c) Karakteristik dan pemahaman atlet, dalam membaca defense lawan

d) Perlu adanya latihan yang terus-menerus, agar atlet lebih memahami tentang pengambilan keputusan shooting dan pembacaan defense lawan.

Analisis ini setelah dikaji mengenai beberapa kelemahan yang perlu pembenahan, maka dapat disampaikan beberapa keunggulan produk ini antara lain :

a) Memberikan pemahaman gerak dasar bagi atlet

b) Memperkaya gerak multilateral bagi atlet

c) Mempermudah pelatih dalam memberikan teori dan pemahaman

d) Waktu yang digunakan bisa dimanfaatkan secara optimal selama 24 detik

e) Tingkat kompetisinya tinggi sehingga membuat atlet lebih bersemangat

Sebagaimana pembahasan diatas, maka adanya faktor psikologis dalam melakukan medium dengan loncatan lebih efektif dan medium shoot tanpa loncatan pada Kejuaraan Bola Basket Pekan Olahraga Wilayah (POPWIL) Se-Wilayah III Cirebon Tahun 2019. Adapun sisi psikologisnya antara lain: kemampuan gerak, rasa percaya diri, keberanian. Serta faktor kondisi fisiknya, antara lain kekuatan, kelentukan, dan koordinasi gerak masih terbatas. 


\section{KESIMPULAN}

Berdasarkan analisis statistik dapat disimpulkan bahwa tidak terdapat perbedaan yang berarti antara medium shoot dengan loncatan dan tanpa loncatan. Medium shoot dengan loncatan lebih efektif daripada medium shoot tanpa loncatan pada Kejuaraan Bola Basket Pekan Olahraga Wilayah (POPWIL) Se-Wilayah III Cirebon Tahun 2019.

\section{Daftar Pustaka}

Ambler, Vic. 2009. Petunjuk untuk Pelatih dan Pemain Bola Basket. Bandung : Pionir Jaya

Arias-Estero, Jose' L., Francisco M. Argudo, dan Jose' I Alonso. 2018. "One-on-one Situation Decision-Making According to Equipment in youth Basketball”, International Journal of Sports Science \& Coaching, Vol. 13 (1).

Arikunto, Suharsimi. 2006. Prosedur Penelitian Suatu Pendekatan Praktik. Jakarta : Rhineka Cipta

Burns, Brian dan Mark Dunning. 2010. Skills in Motion Basketball Step-by-Step. New York: The Rosen Publishing Group.

Canl1, Umut dan Çalık Veli Koçak. 2018. "The Relationship of Shooting Skill with Functional Movement Performance and Attention Level of Basketball Players", Journal of Education and Training Studies. Vol. 6 (12a).

Creswell, John W. 2016. Research Design, Pendekatan Metode Kualitatif, Kuantitatif, dan Campuran. Yogyakarta: Pustaka Pelajar.

Hanna, Sura Jamil dan Saad Alla Abass. "Comparison in Some Kinematic Variables of Lay Up Basketball of Older and Young Players”, Journal of Human Sport \& Exercise, Vol. 10, 2015.

Hantula, Richard. 2012. Science at Work in Basketball. New York: Marshall Cavendish.

Hay, J.G., "The Biomechanics of Sports Techniq", dalam The effects of Increased Shooting Distance in the Basketball Jump Shot diedit oleh Stuart Miller dan Roger M. Bartlett. Journal of Sports Science, Vol. 11, 2007.

Indrawan, Budi dan Deni Nurhidayat. 2010. Permainan Bola Basket. Tasikmalaya : PJKR FKIP UNSIL

Kosasih, Danny. 2010. Fundamental Basketball. Semarang : Karangturi Media

Kusnadi, Nanang dan Enur Nurdin (2010). Ilmu Kepelatihan Dasar. Tasikmalaya : PJKR FKIP UNSIL

Maksum, Ali. 2012. Metodologi Penelitian dalam Olahraga. Surabaya: Unesa University Press.

Marmarinos, Christos. et. al. 2016. "Efficacy of the (Pick and Roll) Offense in Top Level European Basketball Teams”, Journal of Human Kinetics, Vol. 51.

Okazaki, Victor Hugo Alves dan André Luiz Félix Rodacki. "Increased Distance of Shooting on Basketball Jump Shoot”, Journal of Sports Science and Medicine, Vol. 11, 2012.

Okubo, Hiroki dan Mont Hubbard. "Kinematics of Arm Joint Motions in Basketball Shooting”. 7th Asia-Pacific Congress on Sports Technology, Procedia Engineering 112, 2015.

PERBASI. 2018. Peraturan Resmi Bola Basket. Jakarta : PERBASI Indonesia 
Podmenik, Nadja et. al. "The Effect of Shooting Range on The Dynamics of Limbs Angular Velocities of The Basketball Shot”, Journal of Kinesiology, Vol. 49 (1), 2017.

Ruseffendi, E.T (2005). Dasar-dasar Penelitian Pendidikan dan Bidang Non-Ekstra lainnya. Bandung: Tarsito

Shortridge, Ashton, Kirk Goldsberry dan Matthew Adams. "Creating Space to Shoot: Quantifying Spatial Relative Field Goal Efficiency in Basketball”, JQAS, Vol. 10 (3), 2014.

Sobko, Irina. "An Innovative Method of Managing the Training Process of Qualified Basketball Players with Hearing Impairment", Journal of Physical Education and Sport ${ }^{\circledR}$ (JPES), Vol. 15 (4), 2015.

Steciuk, Hanna dan Teresa Zwierko. "Gaze Behavior in Basketball Shooting: Preliminary Investigations", Journal Trends in Sport Sciences, Vol. 2 (22), 2015.

Tangkudung, James. 2013. Kepelatihan Olahraga. Jakarta: Cerdas Jaya.

Winarno. 2011. Metodologi Penelitian Dalam Pendidikan Jasmani. Malang: Media Cakrawala Utama Press.

Wissel. 2012. Basketball: steps to success, third edition. Champaign: Human Kinetics. World Association of Basketball Coaches, Coaches Manual Level 1. Mies: FIBA, 2016. 